\title{
Platform Gamifikasi Untuk Perkuliahan
}

\author{
David Kristiadi*1, Khabib Mustofa ${ }^{2}$ \\ ${ }^{1}$ STMM "MMTC" Yogyakarta; Jl Magelang km. 6 Yogyakarta, Indonesia \\ ${ }^{2}$ Departemen Ilmu Komputer dan Elektronika, FMIPA, UGM, Yogyakarta, Indonesia \\ e-mail: *1dv.davk@gmail.com, ${ }^{2}$ khabib.mustofa@ ugm.ac.id
}

\begin{abstract}
Abstrak
Desain gamifikasi di dalam perkuliahan memiliki banyak variasi. Platform yang fleksibel dibutuhkan untuk mengakomodasi hal tersebut. Penelitian ini bertujuan untuk mengembangkan platform gamifikasi untuk perkuliahan yang fleksibel, memiliki kinerja yang baik dan dapat diterima oleh pengguna.

Platform dikembangkan dengan mengunakan konsep Generic Gamification Platform $(G G P)$. GGP merupakan jenis solusi gamifikasi yang mengaplikasikan prinsip-prinsip Service Oriented Architecture (SOA) dan meletakkan komponen gamifikasi (data, logic dan rewards) terpisah dari Sistem Informasi (SI). Platform dikembangkan dengan kemampuan untuk mengelola game mechanics (mekanika permainan), aksi, task, dan aturan permainan. Selain itu platform juga mampu membangkitkan aturan permainan secara otomatis, dan diintegrasikan dengan SI.

Hasil ujicoba menunjukkan bahwa platform gamifikasi untuk perkuliahan dapat dikembangkan. Platform memiliki tingkat fleksibilitas yang baik, memiliki kinerja yang baik, dan dapat diterima oleh pengguna (5 dosen dan 2 bukan dosen tetapi memahami aktivitas perkuliahan dengan baik). Tingkat fleksibilitas platform sebesar $85 \%$. Waktu respon platform dalam mengeksekusi event kurang dari 336ms. Platform memiliki skor rata-rata System Usability Scale (SUS) sebesar 60.0 dan berada pada range batas bawah yang dapat diterima oleh pengguna.
\end{abstract}

Kata kunci- platform gamifikasi, gamifikasi untuk perkuliahan, GGP, Generic Gamification Platform

\begin{abstract}
Gamification in lecturing has a lot of variety designs. A flexible platform is needed for that matter. This research aims to develop a gamification platform for lecturing that flexible, has a good performance and acceptable by users. Generic Gamification Platform (GGP) concept is used to develop the platform. GGP is a kind of gamification solution that applies service oriented architecture Architecture (SOA) principles and puts gamification components (data, logic and rewards) and Information System (IS) separately. The platform has some capabilities such as able to manage game mechanics, actions, tasks and rules. The other platform's capabilities are able to auto generate rules and to be integrated to IS. The results of tests show that a gamification platform for lecturing can be developed. The platform has a good level of flexibility, has a good performance, and acceptable by users (5 lecturers and 2 nonlecturers but well knowing on lecturing activities). Its flexibility level is $85 \%$. Its average of response time on event execution is lower than 336ms. Its System Usability Scale (SUS) average score is 60 and its acceptability range in low marginal.
\end{abstract}

Keywords - gamification platform, gamification for lecturing, GGP, generic gamification platform

Received December 29 ${ }^{\text {th }}, 2016$; Revised March 13 ${ }^{\text {th }}$, 2017; Accepted July $29^{\text {th }}, 2017$ 


\section{PENDAHULUAN}

$\mathrm{G}$ amifikasi adalah penggunaan unsur-unsur desain game (permainan) pada konteks nonpermainan [1]. Gamifikasi memberikan manfaat yang positif dalam bidang pendidikan yaitu peningkatan motivasi dan keterlibatan (peran aktif) peserta dalam aktivitas pembelajaran yang digamifikasi [2]. Manfaat tersebut diiringi dengan meningkatnya perolehan nilai siswa [3]. Manfaat positif tersebut menjadi daya tarik untuk menjadikan gamifikasi menjadi salah satu pilihan dalam mengelola aktivitas kelas/perkuliahan.

Penerapan gamifikasi membutuhkan perencanaan yang cermat, menyeluruh dan fleksibel [4]. Hal tersebut berkaitan erat dengan aplikasi yang digunakan untuk implementasi gamifikasi (solusi gamifikasi). Di bidang pendidikan khususnya perkuliahan, terdapat beberapa solusi gamifikasi diantaranya sebagai plugin di dalam Learning Management System (LMS), aplikasi kerjasama dengan pihak ketiga dan aplikasi gamifikasi yang dikembangkan sendiri [5]. Walaupun demikian kadang pengguna merasa solusi gamifikasi yang ada kurang fleksibel dan dibatasi oleh lingkungan solusi gamifikasi [5].

Salah satu bentuk solusi gamifikasi berupa platform gamifikasi. Platform gamifikasi merupakan aplikasi yang menyediakan Application Program Interface (API) dan Graphic User Interface (GUI) untuk mengimplementasi desain gamifikasi. Salah satu konsep yang digunakan untuk membangun platform adalah Generic Gamification Platform (GGP). Konsep ini memisahkan komponen gamifikasi dari Sistem Informasi dan menerapkan prinsip-prinsip Service Oriented Architecture (SOA).

Fleksibilitas menjadi salah satu kebutuhan dan prinsip dalam pengembangan platform gamifikasi. Fleksibilitas platform tidak hanya berkaitan dengan integrasi terhadap aplikasi lain, namun juga pada kemampuannya untuk mengakomodasi desain gamifikasi yang berbeda-beda tanpa melakukan perubahan di dalam komponen platform. Fleksibilitas tersebut juga harus didukung oleh kinerja platform yang baik dan dapat diterima oleh pengguna. Sebab fleksibilitas platform yang baik tidak akan berguna tanpa disertai kinerja yang baik atau tidak dapat diterima oleh pengguna. Kebutuhan akan platform gamifikasi untuk perkuliahan yang fleksibel dengan kinerja yang baik serta dapat diterima oleh pengguna menuntun kepada penelitian untuk mengembangkan platform tersebut.

Beberapa penelitian tentang solusi gamifikasi telah dilakukan. Penelitian tersebut berkaitan dengan upaya membangun platform yang fleksibel. Platform yang fleksibel tersebut mudah dimodifikasi untuk digunakan di dalam aplikasi atau lingkungan lain selain dari yang telah dirancang [6]. Upaya yang dilakukan adalah dengan membangun platform gamifikasi yang berorientasi servis [8,9], menggunakan prinsip event-driven [8], adaptif [9], dapat dikonfigurasi dan mendukung mekanika permainan yang bermacam-macam [5]. Namun dari publikasi tersebut belum ada yang secara khusus membahas tentang fleksibilitas platform dalam mengakomodasi desain gamifikasi yang berbeda-beda.

\section{METODE PENELITIAN}

Studi pustaka terhadap literatur-literatur yang berkaitan dengan desain gamifikasi di perkuliahan dan desain platform gamifikasi mengawali proses penelitian. Dari desain-desain tersebut kemudian dilakukan analisa terhadap mekanika permainan yang digunakan, aturanaturan yang digunakan, serta ringkasan umum desain yang dilakukan. Mekanika permainan adalah metode dan alat untuk merepresentasikan data permainan. Beberapa diantaranya adalah poin, badge, leaderboard, level dsb. Banyaknya penggunaan mekanika permainan tidak menjamin keberhasilan penerapan gamifikasi tetapi pada penggunaannya secara efektif [5]. Oleh karenanya platform yang dibangun harus membebaskan game master (dosen) untuk memilih mekanika permainan yang akan digunakan, dan hanya poin yang wajib digunakan [10]. Mekanika permainan yang dukung oleh platform adalah poin, badge, papan skor, level, progression, avatar, status, notifikasi dan activity feed. 


\subsection{Tahapan desain gamifikasi}

Tahapan desain gamifikasi menggunakan platform dirancang seperti pada Gambar 1. Tahap mendefinisikan permainan berkaitan dengan pengisian data profil matakuliah yang digamifikasi seperti nama mata kuliah, tanggal mulai dan berakhirnya kuliah.

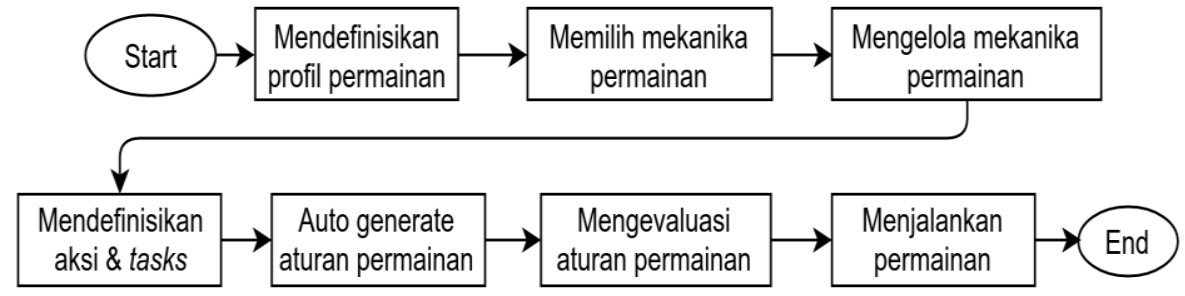

Pada tahap memilih mekanika permainan, game master memilih mekanika permainan yang akan digunakan. Mekanika permainan yang telah dipilih akan diaktifkan dan dapat didefinisikan lebih detail di tahap mengkonfigurasi mekanika permainan. Tahap mendefiniskan aksi dan tasks dilakukan pendefinisian aksi dan kumpulan aksi yang akan dinilai di dalam permainan. Selanjutnya pada tahap auto-generate aturan permainan, aksi dan task yang telah didefinisikan oleh platform akan dipindai dan dimasukkan dimasukkan ke dalam template aturan permainan. Hasil dari proses ini adalah aturan permainan. Selanjutnya game master dapat mengevaluasi aturan permainan yaitu dengan menambah, mengurangi atau memodifikasi aturan. Setelah semua aturan permainan dapat berfungsi dengan baik permainan dapat dijalankan.

\subsection{Perancangan aksi, task, event, eventTask dan aturan permainan}

\subsubsection{Aksi (a)}

Aksi merupakan tindakan-tindakan yang dilakukan oleh pemain untuk memperoleh poin. Aksi memiliki beberapa data penyusun yaitu frekuensi, nilai poin, dan tipe poin. Frekuensi adalah jumlah kemunculan aksi yang diperbolehkan dalam sebuah permainan. Hal ini memungkinkan sebuah aksi yang sama dapat diulang pada sebuah permainan, misalnya pada aksi "kehadiran" pada Tabel 1 dapat diulang sebanyak 14 kali. Nilai poin adalah sejumlah angka yang diterima ketika mengerjakan aksi. Tipe poin menentukan tipe perhitungan poin yang akan diterima oleh pemain. Tipe poin tersebut adalah :

1. Fixed. Seluruh poin yang didefinisikan akan diperoleh hanya dengan mengerjakan aksi.

2. Relative. Poin yang akan diterima pemain ditentukan oleh perbandingan nilai aksi dengan nilai aksi maksimal dikalikan nilai poin, seperti pada persamaan (1)

$$
\text { Poin yang diterima }=\frac{\text { nilai aksi }}{\text { nilai aksi maksimal }} \times \text { nilai poin }
$$

Semisal pemain melakukan aksi "Kehadiran", maka pemain mendapat poin 25. Ketika pemain melakukan aksi "Final Project" dan mendapatkan nilai 7, maka pemain mendapat poin $(7 / 10) * 100=70$.

Tabel 1 Contoh pendefinisian aksi

\begin{tabular}{|l|l|l|c|c|c|}
\hline No & Aksi & Tipe & Kemunculan & Poin & Nilai Max \\
\hline 1 & Kehadiran & Fixed & 14 & 20 & - \\
\hline 2 & Tugas & Relatif & 2 & 100 & 10 \\
\hline 3 & Kuis & Relatif & 1 & 200 & 10 \\
\hline 4 & Ujian & Relatif & 1 & 400 & 10 \\
\hline 5 & Presentasi & Relatif & 1 & 200 & 10 \\
\hline
\end{tabular}

\subsubsection{Task $(t)$}

Task atau sering disebut mission atau challenge merupakan kumpulan dari beberapa aksi yang harus dikerjakan pemain untuk mendapatkan bonus poin atau reward (badge). 
Kumpulan aksi terdiri dari nama aksi dengan jumlah minimal (count) yang harus sudah dikerjakan pada posisi aksi (at) tertentu. Sebagai contoh task "find your sword" pada Tabel 2 , pemain dianggap mengerjakan task tersebut ketika pada Aksi Kehadiran pada posisi (at) yang ke 4, pemain telah mengerjakan minimal sebanyak (count) 2 dan pada Aksi Kuis pada posisi (at) yang ke 1, pemain telah mengerjakannya minimal sebanyak (count) 0. Ketika kondisi tersebut dipenuhi, maka pemain mendapatkan badge "Sword Badge" dan bonus poin 40.

Tabel 2 Contoh pendefinisian tasks

\begin{tabular}{|l|l|l|l|} 
Tasks & Aksi & Bonus Poin & Badges \\
\hline Find your sword & $\begin{array}{l}\text { Kehadiran }(c: 2, \text { at: } 4), \\
\text { Kuis }(c: 0, \text { at: } 1)\end{array}$ & 40 & Sword Badge \\
\hline Facing The Boss & $\begin{array}{l}\text { Kehadiran }(c: 7, \text { at:8), } \\
\text { Tugas }(c: 0, \text { at: } 1)\end{array}$ & 30 & Master Badge \\
\hline
\end{tabular}

Keterangan: $c=$ count/jumlah minimal aksi yang telah dikerjakan; $a t=$ posisi aksi terakhir yang dikerjakan

\subsubsection{Event (e)}

Platform yang dikembangkan juga menggunakan istilah event dan menggunakan asumsi bahwa segala yang berkaitan dengan gamifikasi dapat diwakili oleh event atau user action [8]. Event $(\boldsymbol{e})$ didefinisikan sebagai sebuah peristiwa dimana sebuah aksi $(\boldsymbol{a})$ dikerjakan oleh pemain $(\boldsymbol{p})$ di dalam suatu permainan $(\boldsymbol{g})$ jika dinotasikan seperti pada persamaan 2.

$$
\begin{gathered}
e=(g, p, m, a) \\
\text { dengan } a=\langle\text { code, at }, \text { value }\rangle
\end{gathered}
$$

Pemain (p) dapat bertindak sebagai tim atau pemain tunggal, untuk membedakannya ditambahkan sebuah flag mode tim $(\boldsymbol{m})$. Pemain sebagai tim ketika $\boldsymbol{m}$ bernilai true dan sebagai pemain tunggal ketika $\boldsymbol{m}$ bernilai false. Eksekusi event dengan nilai $\boldsymbol{m}=$ true akan menyebabkan perubahan poin bagi semua anggota tim. Sedangkan perubahan akibat eksekusi event dengan $\boldsymbol{m}=$ false hanya akan diterima oleh pemain sendiri. Di dalam program, event akan dinyatakan ke dalam sebuah objek seperti pada Gambar 2 (a).

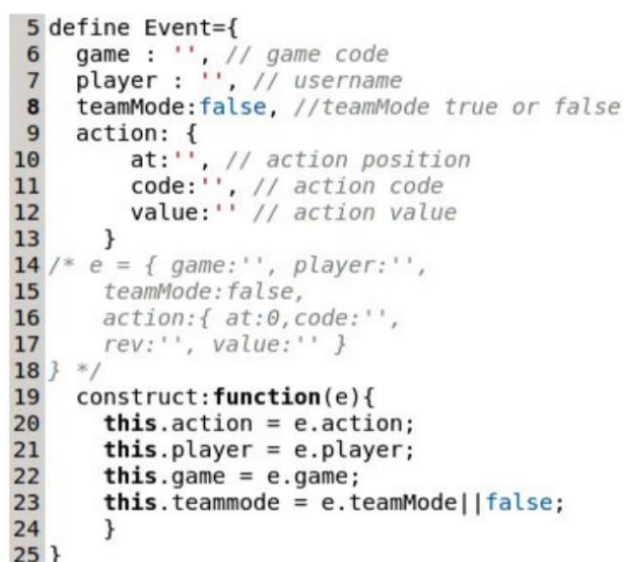

(a)

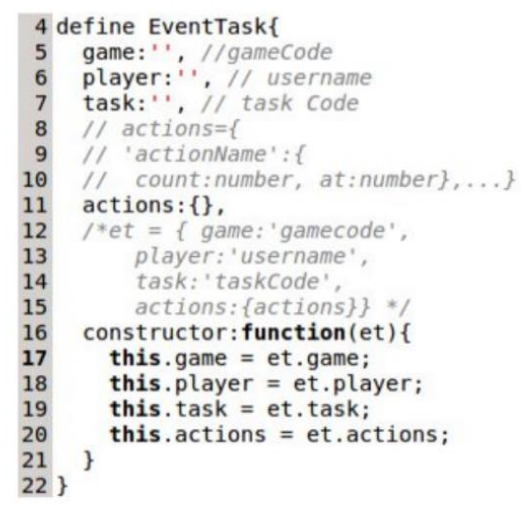

(b)

Gambar 2 Potongan program

(a) Pendefinisian event. (b) Pendefinisian eventTask

Parameter $\boldsymbol{g}$ mewakili kode permainan, $\boldsymbol{p}$ mewakili username pemain atau nama tim, $\boldsymbol{m}$ mewakili flag mode tim dan $\boldsymbol{a}$ mewakili aksi yang dikerjakan pemain. Aksi (a) yang dikerjakan pemain merangkum beberapa data yaitu kode aksi (code), posisi aksi (at) atau urutan aksi yang sedang dikerjakan, dan nilai aksi (value) nilai yang diperoleh pemain (truelfalse untuk tipe aksi fixed dan angka untuk tipe aksi relatif). 


\subsubsection{EventTask (et)}

EventTask merupakan peristiwa dimana pemain $(\boldsymbol{p})$ dari suatu permainan $(\boldsymbol{g})$ telah melakukan sejumlah aksi $\left(\boldsymbol{a}_{\boldsymbol{n}}\right)$ yang dipersyaratkan oleh suatu task $(\boldsymbol{t})$. Hasil dari eksekusi eventTask, pemain mendapatkan rewards sesuai yang telah didefinisikan di task. Jika dinotasikan akan seperti pada persamaan 3.

$$
\begin{gathered}
e t=\left(g, p, t, a_{n}\right) \\
\text { dengan }_{n}=\left\{\text { code }_{1}:\left\langle\text { count }_{\text {at }}\right\rangle, \operatorname{code}_{2}:\langle\text { count }, \text { at }\rangle, \ldots \operatorname{code}_{n}:\langle\operatorname{count}, a t\rangle\right\}
\end{gathered}
$$

EventTask di dalam program dinyatakan dalam bentuk sebuah objek seperti pada gambar Gambar 2 (b). Parameter $\boldsymbol{g}$ mewakili kode permainan, $\boldsymbol{p}$ mewakili username pemain, $\boldsymbol{t}$ mewakili kode task dan parameter $\boldsymbol{a}_{\boldsymbol{n}}$ merupakan rangkuman aksi yang telah dikerjakan pemain. Rangkuman aksi ini berisi daftar kode aksi (code) yang disertai dengan data cacah aksi yang telah dikerjakan (count) dan posisi aksi (at) yang terakhir dikerjakan.

\subsubsection{Rule (aturan permainan)}

Rule atau aturan permainan menggunakan prinsip aturan if-then. Representasi aturan permainan mengikuti format yang telah ditentukan di Domain Specific Language (DSL) dari library Nools (https://github.com/C2FO/nools). Aksi dan task menjadi dasar dalam pembuatan aturan permainan. Pada bagian premis, diambil beberapa properti dari entitas aksi dan task menjadi data pembanding seperti kode permainan, dan kode aksi/task. Pada bagian konklusi properti poin atau reward diambil untuk dijadikan sebagai masukan dalam proses memperbaharui poin dan reward pemain dalam permainan. Dengan prinsip ini aksi dan task yang telah didefinisikan, oleh sistem dapat di auto-generate menjadi aturan permainan dengan menyediakan default template.

\subsection{Rancangan platform}

Platform gamifikasi yang dikembangkan seperti pada Gambar 3. Rancangan ini dikembangkan dari solusi gamifikasi GGP [11] . GGP menerapkan prinsip-prinsip SOA dan menempatkan secara penuh komponen solusi gamifikasi (data dan logic) terpisah dari SI. Pada Gambar 3, frontend merupakan antarmuka bagi pengguna untuk mengakses komponenkomponen di dalam platform atau SI.

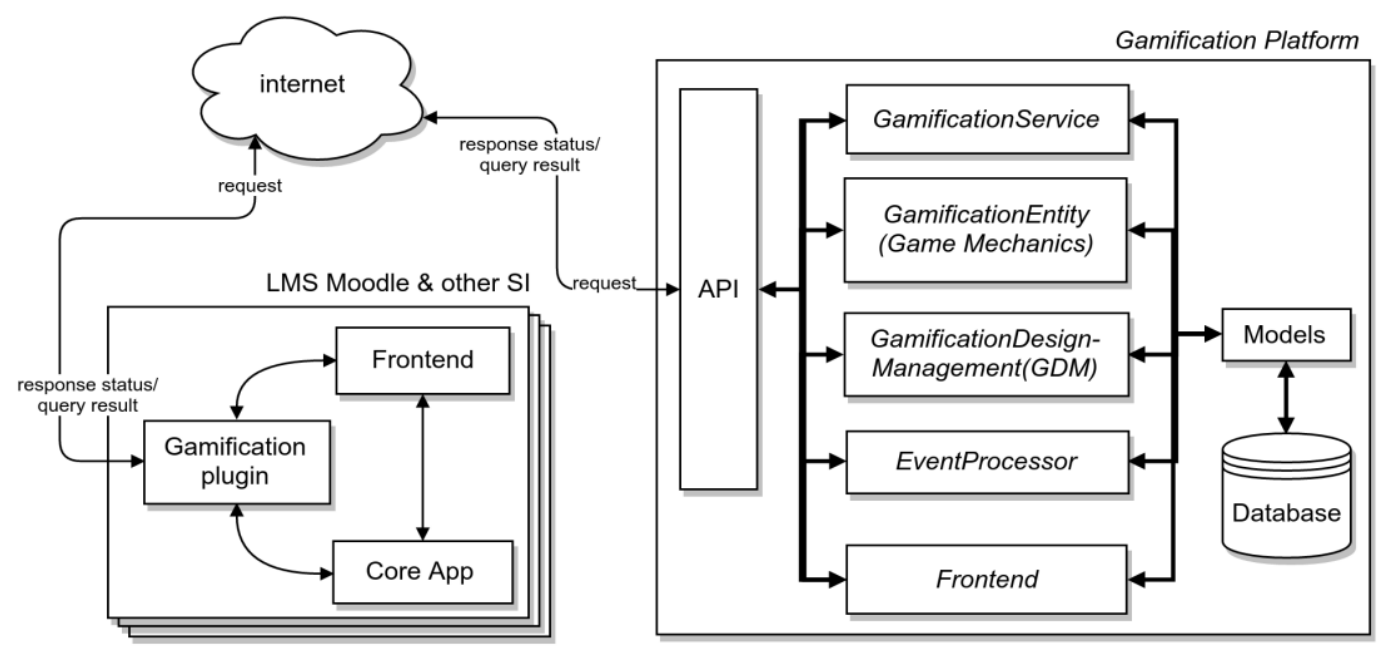

Gambar 3 Rancangan platform gamifikasi pengembangan dari konsep GGP [11] 
Komponen EventProcessor mengerjakan fungsionalitas untuk menambah event. Fungsionalitas platform untuk pengelolaan gamifikasi, pengelolaan aksi dan tasks, pengelolaan tim dan pemain, pengelolaan aturan permainan dirangkum dalam komponen GamificationDesignManagement(GDM). Komponen GamificationEntity merangkum fungsionalitas platform untuk pengelolaan entitas gamifikasi. Komponen GamificationService mewakili proses pengelolaan runtime permainan. Proses CRUD database dikerjakan oleh komponen Model. Plugin gamifikasi berfungsi menjembatani integrasi antara SI dengan platform. Melalui plugin ini, SI dapat melakukan request penambahan event atau request status dan profil pemain. API merupakan webservice yang mengkoordinasikan request dari SI kepada komponen-komponen platform yang lain, kemudian memberikan respon yang berupa hasil query atau status terhadap request yang diinputkan misalnya status HTTP 200 untuk operasi berhasil atau status HTTP 4xx untuk operasi gagal.

\subsubsection{Integrasi Platform dengan SI}

Integrasi platform dengan SI menggunakan contoh kasus LMS Moodle versi 2.6 dan 3.1. Plugin gamifikasi dibangun mengikuti arsitektur LMS, dan dibekali kemampuan berkomunikasi dengan platform melalui RESTful web service. Data yang dipertukarkan antara LMS dengan platform ketika permainan sedang berlangsung adalah event. Oleh karenanya, data penyusun event harus disinkronisasi terlebih dahulu. Data tersebut adalah data pemain, aksi dan permainan. Data pemain disinkronisasi dengan data siswa di LMS. Setiap aktivitas (kuis, ujian/assignment) di LMS disinkronisasi dengan jenis aksi dan posisi aksi (at). Data permainan disinkronisasi dengan data matakuliah/course di LMS. Di dalam LMS melalui plugin dibuat proses untuk me-request sinkronisasi data, me-request penambahan event dan proses mencatat hasil sinkronsisasi.

\subsection{Rancangan Pengujian}

\subsubsection{Uji Fleksibilitas}

Fleksibilitas adalah salah satu kebutuhan non-fungsional platform. Fleksibilitas merupakan kemampuan platform untuk mengakomodasi desain gamifikasi yang berbeda-beda dengan melakukan modifikasi aturan permainan dan pemilihan mekanika permainan tanpa melakukan perubahan pada komponen internal platform. Sehingga platform dapat digunakan untuk matakuliah yang berbeda-beda [7], tanpa melakukan modifikasi komponen internal platform [11, 7]. Untuk mengukur kemampuan platform dalam mengakomodasi desain gamifikasi perkuliahan dirancang sebuah uji fleksibilitas. Di dalam uji fleksibilitas dilakukan implementasi desain gamifikasi yang digunakan oleh beberapa publikasi. Selama pengujian dilakukan pencatatan terhadap beberapa parameter berikut:

1. Mekanika permainan. Parameter ini berkaitan dengan mekanika permainan yang digunakan oleh desain tetapi tidak tersedia di dalam platform.

2. Integrasi LMS/SI. Parameter ini berkaitan dengan perlu atau tidak integrasi dengan LMS/SI melalui plugin gamifikasi yang telah dibuat.

3. Modifikasi aturan. Parameter ini berkaitan dengan perlu atau tidak dilakukan modifikasi aturan permainan.

4. Modifikasi Plugin. perlu tidaknya modifikasi dilakukan modifikasi plugin gamifikasi.

5. Modifikasi Platform, perlu atau tidaknya dilakukan modifikasi internal platform untuk mengakomodasi desain gamifikasi.

6. Kesimpulan. Berupa keterangan desain gamifikasi dapat diakomodasi sepenuhnya, sebagian, atau tidak sama sekali beserta saran agar dapat diakomodasi sepenuhnya. 


\subsubsection{Uji kinerja}

Ujicoba kinerja dilakukan untuk mengetahui waktu respon, tingkat konsumsi CPU dan konsumsi memori platform ketika menangani request penambahan event. Layanan penambahan event melibatkan beberapa proses yang komplek di dalam platform seperti proses eksekusi event dan proses eksekusi eventTask. Pengukuran waktu respon dengan cara menghitung selisih waktu pada awal dan akhir setiap proses tersebut. Waktu respon rata-rata didapatkan dengan menghitung waktu total dibagi dengan jumlah event atau eventTask yang berhasil dieksekusi oleh platform. Pengukuran tingkat konsumsi memori dan CPU dilakukan setiap $300 \mathrm{~ms}$. Pengukuran tersebut dimulai pada awal inisialisasi hingga akhir uji kinerja.

Uji kinerja dilakukan dengan cara mengirimkan sejumlah request penambahan event kepada platform. Untuk itu dibuat lingkungan ujicoba yang terdiri dari $2^{n}$ permainan dengan $n=(1,2, \ldots, 7)$. Setiap permainan dikuti oleh 20 pemain. Setiap permainan memiliki 5 macam aksi tunggal (teamMode $=$ false) dengan komposisi seperti pada Tabel 1. Ditentukan 2 macam task, dengan jumlah minimal (count) setiap aksi ditentukan secara random dan posisi aksi (at) adalah nilai frekuensi aksi. Dengan ini setiap permainan akan ada 400 event dan 40 eventTask jika diasumsikan semua pemain mengerjakan semua event dan eventTask yang dibuat.

\subsubsection{Uji usabilitas}

Untuk mengetahui tingkat penerimaan calon pengguna terhadap platform yang telah dibuat dilakukan uji Usabilitas. Uji usabilitas menggunakan metode System Usability Scale (SUS) [12]. Ujicoba dilakukan dengan melibatkan 9 responden. Jumlah ini memenuhi syarat jumlah minimal untuk melakukan uji usabilitas yaitu 5 orang [13]. Responden yang ikut serta dalam uji usabilitas adalah pengajar diperkuliahan atau memahami aktivitas perkuliahan dengan baik. Responden memiliki latar belakang yang bervariasi. Hal ini bertujuan untuk membuktikan bahwa platform dapat digunakan oleh semua dosen. Skenario yang digunakan untuk ujicoba ini sebagai berikut :

1. Responden mendengarkan penjelasan tentang gamifikasi dan cara penggunaan platform.

2. Responden mempraktekkan penggunaan platform (dengan bantuan dan tanpa bantuan)

3. Responden membuat desain gamifikasi dari soal yang disediakan, kemudian menginputkannya ke dalam platform tanpa disertai bantuan.

4. Setelah responden melewati tahapan di atas, responden diperbolehkan mengisi kuisioner. Pertanyaan kuisioner terbagi menjadi 3 bagian. Bagian pertama kuisioner berisi pertanyaan untuk mengetahui tingkat pemahaman responden tentang konsep gamifikasi perkulihan dan penggunaan platform. Bagian kedua kuisioner berisi pertanyaan dari uji usabilitas menggunakan metode SUS. Bagian ketiga adalah pendapat pengguna tentang fitur platform dan saran pengguna untuk perbaikan.

\subsection{Implementasi}

Gambar 4 adalah hasil implementasi pada platform dan plugin gamifikasi. Implementasi platform dilakukan dengan menggunakan lingkungan pemrograman Javascript, dan database Mysql. Sedang untuk plugin gamifikasi menyesuaikan dengan lingkungan LMS moodle yaitu pemrograman PHP dan database MySQL. 


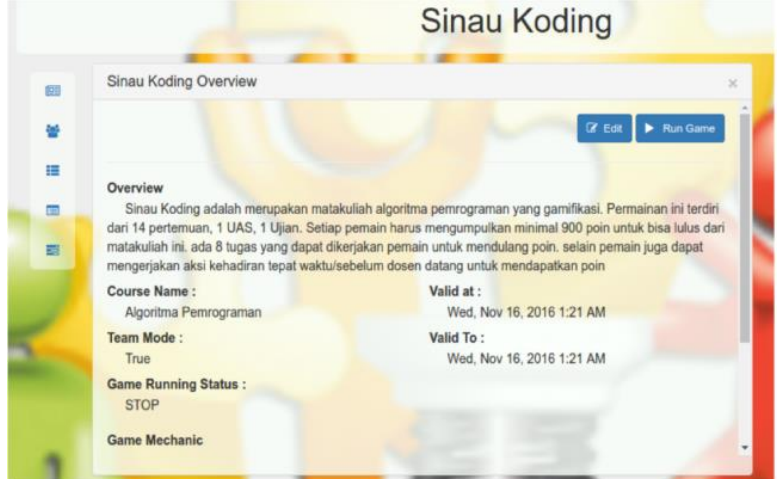

(a)

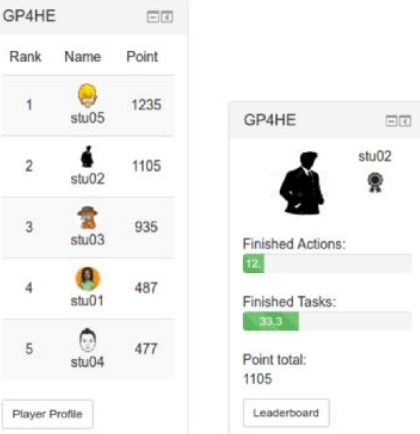

(b)

(c)

Gambar 4 Hasil implementasi platform dan plugin gamifikasi.

(a) Tampilan permainan pada platform gamifikasi; (b) Tampilan leaderboard di plugin gamifikasi;

(c) Tampilan status dan profil pemain di plugin gamifikasi.

\section{HASIL DAN PEMBAHASAN}

Uji fleksibilitas yang dilakukan adalah dengan cara mengimplemetasikan desain gamifikasi yang digunakan pada beberapa publikasi. Ada 10 desain gamifikasi dari 10 publikasi yang diujikan. Tabel 3 adalah hasil uji coba implementasi desain. Hasil uji fleksibilitas menunjukkan bahwa dari 10 desain gamifikasi yang digunakan untuk uji fleksibilitas, $85 \%$ dapat diimplementasikan menggunakan platform. Dari hasil tersebut terbukti bahwa platform fleksibel atau dapat mengakomodasi desain gamifikasi yang bermacam-macam tanpa harus merubah internal platform.

Tabel 3 Hasil uji fleksibilitas platform

\begin{tabular}{|c|c|c|c|c|c|c|c|c|}
\hline \multirow{2}{*}{ No } & \multirow{2}{*}{$\begin{array}{l}\text { Publi- } \\
\text { kasi }\end{array}$} & \multicolumn{2}{|c|}{ Mekanika } & \multirow{2}{*}{ Integrasi SI } & \multirow{2}{*}{$\begin{array}{l}\text { Atu- } \\
\text { ran }\end{array}$} & \multicolumn{2}{|c|}{ Modifikasi } & \multirow{2}{*}{ Kesimpulan } \\
\hline & & $\begin{array}{l}\text { Yg di- } \\
\text { gunakan }\end{array}$ & $\begin{array}{l}\text { Yg tdk } \\
\text { tersedia }\end{array}$ & & & & & \\
\hline 1 & {$[18]$} & $\begin{array}{l}\text { (a), (b), (c), } \\
\text { (d), (f) }\end{array}$ & - & $\begin{array}{c}\sqrt{ } \\
(\text { Moodle })\end{array}$ & - & $\sqrt{ }$ & - & $\begin{array}{l}\text { Desain terakomodasi sepenuhnya. } \\
\text { Pengembangan plugin untuk aktivitas forum }\end{array}$ \\
\hline 2 & [19] & (a), (b), (e) & - & - & - & - & - & Desain terakomodasi sepenuhnya \\
\hline 3 & {$[5]$} & $\begin{array}{l}\text { (a), (b), (c), } \\
\text { (d) }\end{array}$ & Virtual goods & $\begin{array}{c}\sqrt{ } \\
\text { (Moodle) }\end{array}$ & - & - & $\begin{array}{c}\sqrt{ } \\
{[\text { seba- }} \\
\text { gian] }\end{array}$ & $\begin{array}{l}\text { Terakomodasi sebagian, dukungan terhadap } \\
\text { virtual goods perlu ditambah }\end{array}$ \\
\hline 4 & [4] & (a), (b), (c) & - & $\begin{array}{l}\quad \sqrt{ } \\
\text { (Dapat menggu- } \\
\text { nakan Moodle) }\end{array}$ & - & $\sqrt{ }$ & - & Terakomodasi sepenuhnya. \\
\hline 5 & [3] & (a), (b), (d) & - & $\begin{array}{l}\quad \sqrt{ } \\
\text { (Dapat menggu- } \\
\text { nakan Moodle) }\end{array}$ & - & $\sqrt{ }$ & - & $\begin{array}{l}\text { Terakomodasi sepenuhnya. Pengembangan } \\
\text { plugin untuk aksi survei }\end{array}$ \\
\hline 6 & [20] & (a), (b) & - & $\sqrt{ }$ & - & $\sqrt{ }$ & - & $\begin{array}{l}\text { Terakomodasi sepenuhnya. Pengembangan } \\
\text { plugin untuk aktivitas diforum seperti post, } \\
\text { assist dan like }\end{array}$ \\
\hline 7 & {$[14]$} & (a), (e) & - & - & $\sqrt{ }$ & - & - & Terakomodasi sepenuhnya \\
\hline 8 & {$[15]$} & $\begin{array}{l}\text { (a), (b), } \\
\text { (d), (g), (h) }\end{array}$ & - & - & $\sqrt{ }$ & $\sqrt{ }$ & - & $\begin{array}{l}\text { Terakomodasi sepenuhnya. Pengem-bangan } \\
\text { front end plugin untuk menampilkan } \\
\text { leaderboard sesuai desain. }\end{array}$ \\
\hline 9 & [16] & (a), (c), (e) & $\begin{array}{l}5 \text { kategori } \\
\text { poin, virtual } \\
\text { economy }\end{array}$ & $\sqrt{ }$ & $\sqrt{ }$ & $\sqrt{ }$ & $\sqrt{ }$ & $\begin{array}{l}\text { Tidak terakomodasi. Perlu pengembangan } \\
\text { platform untuk mendukung } 5 \text { jenis kategori } \\
\text { poin dan mekanika virtual economy }\end{array}$ \\
\hline 10 & [17] & (a),(e) & - & - & - & - & - & Terakomodasi sepenuhnya. \\
\hline
\end{tabular}

Keterangan: (a) poin/skor. (b) papan skor. (c) badges. (d) progress/completion track. (e) level. (f) status. (g) activity feed/instant feedback. (h) avatar. $\sqrt{ }$ : ya. - : tidak 
Agar dapat mengakomodasi seluruh desain, perlu dilakukan modifikasi platform dengan menambah dukungan terhadap penggunaan mekanika virtual goods, virtual economy dan poin dengan bermacam-macan kategori. Internal komponen di dalam rancangan (Gambar 3) harus dimodifikasi seperti (a) Komponen GamificationEntity perlu ditambahkan kemampuan untuk mengelola mekanika tersebut. (b) Komponen GamificationDesignManagement perlu ditambahkan pilihan kategori poin ketika mendefinisikan aksi. (c) Komponen EventProcessor perlu ditambahkan proses yang mengeksekusi event yang menyebabkan perubahan data pemain terkait mekanika tersebut. (d) Di dalam Model perlu ditambahkan modul untuk mengakses database yang berkaitan dengan data mekanika tersebut. (e) Komponen Frontend harus ditambahkan antarmuka yang berkaitan dengan pengelolaan mekanika poin dengan kategori yang bermacam, virtual goods dan virtual economy

Ujicoba kinerja platform dilakukan secara lokal, yaitu menggunakan satu komputer sebagai server dan klien. Pengujian menggunakan spesifikasi komputer dengan sistem operasi Linux Mint 17.3 64Bit, CPU AMD A6-4455 2.1 GHz dan memory 7623MB. Gambar 5 (a) adalah grafik waktu respon rata-rata dalam mengeksekusi event dan eventTask. Hingga cacah permainan yang dijalankan sekaligus sejumlah 128 permainan. Waktu respon rata-rata untuk mengeksekusi event $\left(t_{A}+t_{B}\right)$ adalah $336 \mathrm{~ms}$. Waktu respon yang dibutuhkan platform untuk melayani eventTask $\left(t_{C}+t_{D}\right)$ adalah $711 \mathrm{~ms}$. Waktu respon tersebut dapat dikatakan cepat karena tidak lebih dari 1 detik [21]. Selain itu mengingat juga akan banyaknya permainan dan event yang harus diproses oleh platform. Penambahan cacah permainan yang dijalankan, selain menambah variasi event yang dieksekusi, juga menambah layanan yang memastikan runtime permainan tetap ada di memori.

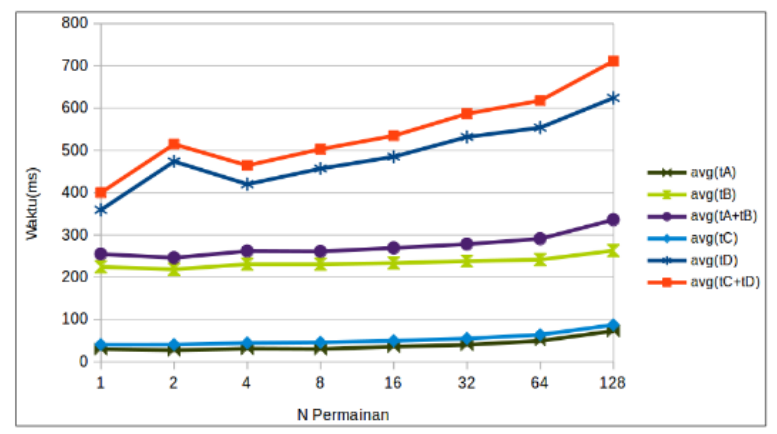

(a)

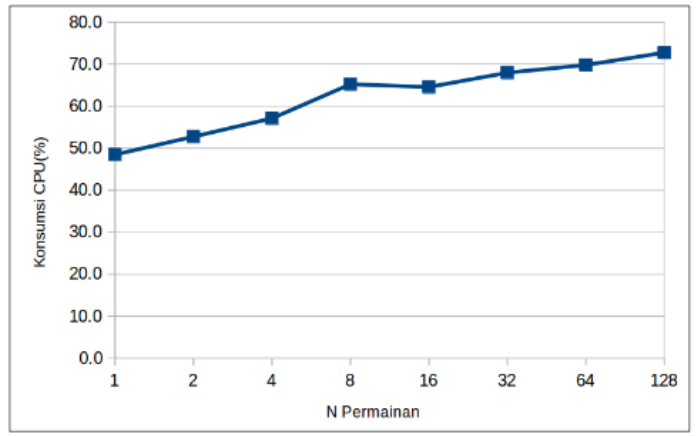

(b)

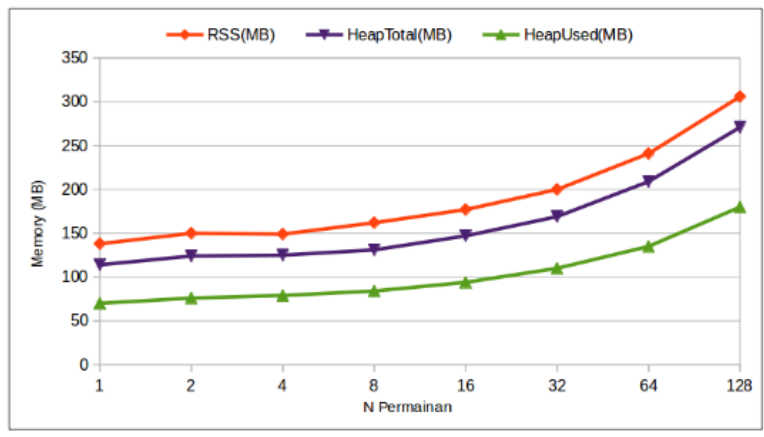

(c)

Gambar 5: Grafik hasil uji kinerja platform dalam melayani request penambahan event (a) waktu respon platform; (b) tingkat penggunaan CPU; (c) Tingkat penggunaan memori

Hingga cacah permainan yang dijalankan sekaligus mencapai 128 permainan, rata-rata tingkat konsumsi CPU yang tertinggi adalah 73\% Gambar 5 (b) dan rata-rata konsumsi memori (RSSResident set/ alokasi memori yang digunakan oleh aplikasi) yang tertinggi adalah 306MB 
Gambar 5 (c). Ini berarti bahwa platform dapat bekerja dengan baik tanpa harus menghabiskan sumber daya yang ada. Sehingga dapat disimpulkan bahwa platform dapat bekerja dengan baik walaupun dalam lingkungan yang terbatas. Untuk meningkatkan hasil uji kinerja dapat dilakukan (1) memperbesar kapasistas hardware yang digunakan untuk menjalankan platform seperti meningkatkan kecepatan CPU dan kapasitas memori, (2) meminimalisir bug, (3) mengganti algoritma yang kurang efisien dengan yang lebih efisien.

Untuk hasil uji usabilitas, dari 9 responden yang ikut serta hanya 7 responden yang dapat menyelesaikan tahapan uji usabilitas dan memiliki jawaban benar minimal $80 \%$ pada pertanyaan bagian pertama. Dari ketujuh responden tersebut 5 adalah dosen dan 2 bukan dosen namun memahami aktivitas perkuliahan dengan baik. Sebanyak $42,8 \%$ responden memberikan penilaian dengan total skor SUS bernilai lebih dari sama dengan 70 dan yang lainnya kurang dari 70. Skor SUS sama dengan 70 merupakan batas minimal yang termasuk dalam range dapat diterima sepenuhnya oleh pengguna [22]. Rata-rata total skor SUS adalah 60.0. Skor tersebut berdasarkan perbandingan rata-rata skor SUS [22] memiliki peringkat D, sifat OK dan berada pada batas bawah untuk dapat diterima pengguna. Tabel 4 adalah rata-rata skor SUS dari setiap pernyataan SUS.

Tabel 4 Hasil uji usabilitas platform gamifikasi

\begin{tabular}{|l|l|c|}
\hline No & Pernyataan & Rata $^{2}$ skor SUS \\
\hline Q1 & Saya akan sering menggunakan sistem ini & 2.3 \\
\hline Q2 & Sistem ini seharusnya sederhana & 1.1 \\
\hline Q3 & Sistem ini mudah digunakan & 2.6 \\
\hline Q4 & Saya perlu bantuan tenaga teknis agar dapat menggunakan sistem ini & 2.6 \\
\hline Q5 & Beberapa fungsi pada sistem ini terintegrasi dengan baik & 3.1 \\
\hline Q6 & Terlalu banyak ketidakkonsistenan pada sistem ini & 2.6 \\
\hline Q7 & Pada umumnya orang-orang akan belajar menggunakan sistem dengan cepat & 2.3 \\
\hline Q8 & Sistem sangat rumit digunakan & 2.6 \\
\hline Q9 & Saya merasa percaya dan nyaman menggunakan sistem ini & 2.7 \\
\hline Q10 & Saya harus belajar banyak hal sebelum menggunakan sistem ini & 2.1 \\
\hline & Total Skor SUS rata-rata = total $* 2.5$ & 60.0 \\
\hline
\end{tabular}

Pernyataan Q4, Q7, dan Q10 memiliki skor rata-rata di atas 2 ini menunjukkan bahwa platform cenderung mudah dipelajari. Informasi yang cukup tentang konsep dan cara penggunaan platform, membuat pengguna dapat menyelesaikan tugas membuat desain gamifikasi secara mandiri/tanpa bantuan teknisi. Skor pada Pernyataan Q2 bernilai 1.1. Skor tersebut menunjukkan bahwa perlu dilakukan perbaikan terhadap tahapan membuat desain gamifikasi pada Gambar 1 dan antarmuka. Rata-rata skor SUS pada Pernyataan Q5 dan Q6 masing-masing bernilai 3.1 dan 2.6. Skor tersebut berarti pengguna menemukan bahwa platform dapat berfungsi dengan baik. Skor tersebut juga mendukung hasil uji kinerja, yaitu bahwa platform memiliki kinerja yang baik.

Untuk meningkatkan hasil uji usabilitas platform perlu dilakukan beberapa hal yaitu (1) pengembangan lebih lanjut pada bagian antar muka, (2) penyederhanaan tahapan desain gamifikasi, (3) menyediakan template desain gamifikasi atau mendukung kemampuan platform untuk menduplikasi desain gamifikasi dan (4) memperbanyak pelatihan, manual dan tutorial penggunaan platform. 


\section{KESIMPULAN}

Penelitian tentang pengembangan platform gamifikasi untuk perkuliahan dengan Konsep Generic Gamification Platform (GGP) berhasil dilakukan. Penelitian ini menghasilkan beberapa kesimpulan, yaitu:

1. Platform yang telah dikembangkan memiliki fleksibilitas yang baik/dapat mengakomodasi desain gamifikasi perkuliahan yang berbeda-beda tanpa membutuhkan modifikasi internal platform. Dari 10 desain gamifikasi yang berbeda dapat diakomodasi menggunakan platform sebesar $85 \%$.

2. Platform yang telah dikembangkan memiliki kinerja yang baik. Waktu respon rata-rata kurang dari 1 detik yaitu untuk eksekusi event kurang dari $336 \mathrm{~ms}$ dan eksekusi eventTask kurang dari 711 ms. Tingkat konsumsi CPU 73\% dan memori $306 \mathrm{MB}$.

3. Platform yang telah dikembangkan dapat diterima oleh pengguna ( 5 dosen dan 2 bukan dosen tetapi memahami dengan baik aktivitas perkuliahan).Total skor SUS rata-rata platform adalah 60. Dengan skor tersebut platform memiliki peringkat kata sifat "OK", nilai $\mathrm{D}$ dan berada pada range batas bawah yang dapat diterima oleh pengguna.

4. Bagian platform yang terbukti mendukung fleksibilitas platform adalah bagian pemilihan mekanika permainan, pengelolaan mekanika permainan, pendefinisian aksi, pendefinisian task, pengelolaan aturan permainan, dan integrasi dengan aplikasi lain.

\section{SARAN}

Tahapan desain gamifikasi dan antar muka platform perlu dibuat menjadi lebih sederhana untuk lebih memudahkan pengguna dalam menggunakan aplikasi. Pengembangan platform untuk mendukung mekanika permainan yang belum didukung seperti virtual goods, dan virtual economy. Pengembangan plugin LMS Moodle lebih lanjut untuk mendukung aktivitas selain assignment dan quize. Pengembangan plugin gamifikasi untuk LMS selain Moodle.

\section{UCAPAN TERIMA KASIH}

Penulis mengucapkan terima kasih kepada Balitbang SDM Kominfo yang telah memberi dukungan finansial terhadap penelitian ini.

\section{DAFTAR PUSTAKA}

[1] Deterding, S., Dixon, D., Khaled, R. \& Nacke, L.E., 2011, Gamification: Toward a Definition, CHI 2011 Gamification Workshop Proceedings, hal. 12-15.

[2] Hamari, J., Koivisto, J. \& Sarsa, H., 2014, Does Gamification Work? - A Literature Review of Empirical Studies on Gamification, 2014 47th Hawaii International Conference on System Science, vol. 47, hal. 3025-3034.

[3] Domínguez, A., Saenz-de-navarrete, J., Fernández-sanz, L., Pagés, C. \& De-Marcos, L., 2013, Gamifying learning experiences: Practical implications and outcomes, Computers \& Education, vol. 63, hal. 380-392.

[4] Ibanez, M.-B., Di-Serio, A. \& Delgado-kloos, C., 2014, Gamification for Engaging Computer Science Students in Learning Activities: A Case Study, IEEE Transactions on Learning Technologies, Vol. 7, No. 3, Juli-September 2014, hal. 291-301.

[5] Dicheva, D., Irwin, K., Dichev, C. \& Talasila, S., 2014, A Course Gamification Platform Supporting Student Motivation and Engagement, 2014 International Conference on Web and Open Access to Learning (ICWOAL), hal. 1-4. 
[6] IEEE, 2010, Systems and software engineering -- Vocabulary, ISO/IEC/IEEE 24765:2010(E), hal. 1-418.

[7] Haaranen, L., Hakulinen, L., Ihantola, P. \& Korhonen, A., 2014, Software Architectures for Implementing Achievement Badges - Practical Experiences, 2014 International Conference on Teaching and Learning in Computing and Engineering Software, hal. 4146.

[8] Herzig, P., Ameling, M. \& Schill, A., 2012, A Generic Platform for Enterprise Gamification, 2012 Joint Working Conference on Software Architecture \& 6th European Conference on Software Architecture, hal. 219-223.

[9] Monterrat, B., Lavoué, É. \& George, S., 2014, Motivation for Learning: Adaptive Gamification for Web-based Learning Environments, 6th International Conference on Computer Supported Education scenario, hal. 117-125.

[10] Zichermann, G. \& Cunningham, C., 2011, Gamification by Design: Implementing Game Mechanics in Web and Mobile Apps, 1 ed. Sebastopol, CA: O'Reilly Media.

[11] Herzig, P., Ameling, M., Wolf, B. \& Schill, A., 2015, Implementing Gamification: Requirements and Gamification Platforms, Gamification in Education and Bussiness, hal. $1-21$.

[12] Brooke, J., 1996, SUS - A quick and dirty usability scale, Usability Evaluation in Industry, no. 189, hal. 189-194.

[13] Sauro, J., 2013, 10 Things to Know About the System Usability Scale (SUS). http://www.measuringu.com/blog/l0-things-SUS.php, diakses tgl 12 Maret 2016.

[14] Laskowski, M. \& Badurowicz, M., 2014, Gamification in higher education: a case study, Management, Knowledge and Learning (MakeLearn) International Conference 2014, hal. 971-975.

[15] Todor, V. \& Pitică, D., 2013, The gamification of the study of electronics in dedicated elearning platforms, 36th Int. Spring Seminar on Electronics Technology, hal. 428-431.

[16] Swacha, J. \& Baszuro, P., 2013, Gamification - based e - learning Platform for Computer Programming Education, X World Conference on Computers in Education, hal. 122-130.

[17] Lambruschini, B.B. \& Pizarro, W.G., 2015, Tech - Gamification in university engineering education: Captivating students, generating knowledge, in International Conference on Computer Science \& Education (ICCSE 2015), hal. 295-299.

[18] Amriani, A., Aji, A.F., Utomo, A.Y. \& Junus, K.M., 2013, An Empirical Study of Gamification Impact on E-Learning Environment, Proceedings of 2013 3rd International Conference on Computer Science and Network Technology, hal. 265-269.

[19] Borys, M. \& Laskowski, M., 2013, Implementing game elements into didactic process: a case study, Management, Knowledge and Learning International Conference 2013, hal. 819-824.

[20] Grant, E.S., Shankararaman, V. \& Loong, J.L.K., 2014, Experimenting with Gamification in the Classroom, 2014 IEEE 6th International Conference on Engineering Education gamification, hal. 79-83.

[21] Neilsen, J., 2010, Website Response Times. https://www.nngroup.com/articles/websiteresponse-times/, diakses tgl 07 November 2016.

[22] Bangor, A., Staff, T., Kortum, P., Miller, J. \& Staff, T., 2009, Determining What Individual SUS Scores Mean: Adding an Adjective Rating Scale, Jurnal of Usability Studies, vol. 4, no. 3, hal. 114-123. 